\title{
Eco-friendly Wood-biofungicidal and Antibacterial Activities of Various Coccoloba uvifera L. Leaf Extracts: HPLC Analysis of Phenolic and Flavonoid Compounds
}

\author{
Nader A. Ashmawy, ${ }^{\text {a }}$ Mohamed Z. M. Salem, ${ }^{\text {b } *}$ Nader El Shanhorey, ${ }^{c}$ \\ Asma A. Al-Huqail, ${ }^{\mathrm{d}} * *$ Hayssam M. Ali, ${ }^{\mathrm{d}}$ and Said I. Behiry ${ }^{\mathrm{e}}$
}

\begin{abstract}
Aqueous, acetone, and ethanol extracts of Coccoloba uvifera L. (Polygonaceae) leaves were assessed for their antibacterial and antifungal activities. The fungal pathogens Fusarium culmorum, Rhizoctonia solani, and Botrytis cinerea were isolated from strawberry plants, and they were molecularly identified through internal transcribed spacers (ITS) sequence analysis. Wood treated with ethanol extract at 3\% showed the highest inhibition of $R$. solani, B. cinerea, and F. culmorum growth, with mycelial growth inhibited by $64.4 \%, 100 \%$, and $38.5 \%$, respectively. Moderate growth inhibition was found against the plant pathogenic bacteria Agrobacterium tumefaciens, Pectobacterium carotovorum subsp. carotovorum, Erwinia amylovora, Ralstonia solanacearum, Pectobacterium atrosepticum, and Dickeya solani. Highperformance liquid chromatography analysis identified the phenolic and flavonoid compounds in the extracts. Regarding phenolic acid compounds, benzoic, ellagic, gallic, and o-coumaric acids were found as the main compounds in ethanol, acetone, and aqueous extracts. Regarding flavonoids, rutin, myricetin, and quercetin were identified in aqueous, acetone, and ethanol extracts. The results suggesting that the extracts can be used as environmentally friendly bioagents.
\end{abstract}

Keywords: Coccoloba uvifera leaves; Phenolic compounds; Flavonoid compounds; HPLC analysis; Antimicrobial activity

Contact information: a: Plant Pathology Department, Faculty of Agriculture (EL-Shatby), Alexandria University, Alexandria, Egypt; b: Forestry and Wood Technology Department, Faculty of Agriculture (ELShatby), Alexandria University, Alexandria, Egypt; c: Department of Botanical Gardens Research, Horticultural Research Institute (ARC), Alexandria, Egypt; d: Chair of Climate Change, Environmental Development and Vegetation Cover, Department of Botany and Microbiology, College of Science, King Saud University, Riyadh 11451, Saudi Arabia; e: Agricultural Botany Department, Faculty of Agriculture (Saba Basha), Alexandria University, Alexandria 21531, Egypt; *Corresponding authors: Mohamed Z.M. Salem (zidan_forest@yahoo.com); AsmaA.Al-Huqail (aalhuqail@ksu.edu.sa)

\section{INTRODUCTION}

Natural extracts from various species of the genus Coccoloba (approximately 120 to 150 species), have been reported to have antimicrobial activities (Li et al. 1999; Perez et al. 2001; Cota et al. 2003; Meléndez and Capriles 2006; Sharma et al. 2017). These biological activities have been revealed to be due to the presence of phenolic or flavonoidtype compounds (Compagnone et al. 1995; Li et al. 1999; Campos et al. 2015; Povi et al. 2015), terpenoids (Cota et al. 2003), benzenoids (Li et al. 1999), and carboxylic acids and esters (Shaw et al. 1992). EL-Hefny et al. (2019) suggested the potential uses of essential oil and recovery oil from the fresh flowers Matricaria chamomilla as environmentally 
friendly bio-fungicides against Aspergillus niger, A. flavus, A. terreus, and Fusarium culmorum.

Coccoloba uvifera L. belongs to the Polygonaceae family, and it is found naturally in the Antilles, the Bahamas, the South American tropical places, and on the Venezuelan coast, where it is commonly known as "sea grape". Its leaves have been used to treat dysentery, diarrhea, asthma, wounds, and skin diseases (Adonizio et al. 2006; Boulogne et al. 2011). The ethyl acetate fraction from the methanolic extract of $C$. uvifera L. seeds contains a tannic compound (gallic acid), an organic acid (hexenedioic acid), and a benzopyran (1,3,4,6,7,8-hexahydro-4,6,6,8,8,8-hexamethylcyclopenta-2-benzopyran) having antifungal activities against Candida albicans, Fusarium oxysporum, and $F$. decencellulare as well as antibacterial activities against Salmonella typhimurium and Staphylococcus aureus (Moreno-Morales et al. 2008).

Anthocyanins, ascorbic acid, phenolic compounds, and flavonoids with free radical scavenging and antioxidant properties have been identified in fruit extracts of $C$. uvifera (Campos et al. 2015). In addition, the ethanol and water extracts of $C$. uvifera leaves have effective antioxidant agent, as measured by 2,2-diphenyl-1-picrylhydrazyl (DPPH) radical scavenging and weak antibacterial properties (Kaewpiboon et al. 2012). Emodin, chrysophanol, physcion, rhein, royleanone, $\alpha$-amyrin, and $\beta$-sitosterol have also isolated from the extracts of shade-dried $C$. uvifera leaves (Malathi et al. 1995).

Potato bacterial pathogens are responsible for serious plant and tuber damages. Dickeya and Pectobacterium bacterial species are characterized as potato pathogens, and cause soft rot disease in tubers, as well as blackleg and wet rot diseases in stems (Van der Wolf and De Boer 2007; Ashmawy et al. 2014, 2015a, 2020; Behiry et al. 2018a). Pectobacterium atrosepticum and Dickeya blackleg symptoms appear to spread as slim wet and rotted-black lesions from the parent tuber to the stems under humid conditions (Pitman et al. 2010; Ashmawy et al. 2015a). Furthermore, Ralstonia solanacearum, a bacterial wilt and potato brown disease agent, is classed as one of the most severe Egyptian bacterial plant diseases (Behiry et al. 2018b; Mohamed et al. 2019).

Erwinia amylovora, the causal agent of fire blight disease, is one of the most destructive bacteria that can attack apple and pear fruit trees, and pear plantations in Egypt (Ashmawy et al. 2015b). Agrobacterium tumefaciens (synonym Rhizobium radiobacter) is the causal agent of crown gall disease in over 140 species of dicots (Young et al. 2001), including many trees, as well as grassy plants (DeCleene and DeLey 1976).

Black root rot is a serious disease triggered by one or more fungal genera, including F. oxysporum (Juber et al. 2014), Pythium spp. (Abdel-Sattar et al. 2008), Phytophthora spp. (Mingzhu 2011), and Rhizoctonia spp. (Fang et al. 2013).

Several synthetic chemical substances that are deemed to efficiently and effectively control many plant pathogens can cause serious injury to crops, particularly citrus. The continued use of these residual toxic synthetic bactericides leads to soil and water pollutions (Pimentel and Levitan 1986). Consequently, the use of plant extracts or the essential oils to combat bacterial and fungal plant diseases has become a significant component of integrated pest management, as they are environmentally friendly natural bactericides (EL-Hefny et al. 2017a, 2017b; Ashmawy et al. 2018a, 2018b; Behiry et al. 2019a; Okla et al. 2019; Behiry et al. 2020; Mohamed et al. 2020).

Although the application of chemical compounds has serious detrimental effects on environmental and human health, it can sometimes accomplish significant results. This is why manufacturers struggle to stop and substitute these hazardous chemicals with less harmful products (Ahmed and El-Fiki 2017). Synthesized substances are limited in their 
usefulness because of their excessive toxicity and because grey mold fungicides are usually applied at least one week before harvest, and this is deemed unacceptable. As a potential solution, it is possible to control strawberry grey mold disease with natural products and immunity inducers, which can increase plant defense (Awad 2017).

The aim of the present study was to evaluate the antimicrobial activities of different solvent extracts from $C$. uvifera leaves against the growth of some phytopathogenic bacterial and fungal strains. Furthermore, to identify the phenolic/caffeine and flavonoid type of compounds in the leaf extracts using high-performance liquid chromatography (HPLC) analysis.

\section{EXPERIMENTAL}

\section{Materials}

Extraction and preparation of Coccoloba uvifera L. leaf extracts

Coccoloba uvifera L. leaves were collected from Alexandria, Egypt during January 2018, and were washed using tap water. The leaves were then air-dried for two weeks under laboratory room conditions before being ground into small pieces using a small laboratory mill. The ground leaf materials were divided into three groups, fifty grams for each; the first group was soaked with distilled water $(200 \mathrm{~mL})$, the second soaked with $90 \%$ acetone $(200 \mathrm{~mL})$, and the third soaked with $96 \%$ ethanol $(200 \mathrm{~mL})$ for one week (Salem et al. $2019 b$ ). At the end of the extraction process, the soaked materials were filtered using Whatman No. 1 filter paper. The solvents were removed using a rotary evaporator at $45^{\circ} \mathrm{C}$ (Salem et al. 2013). The crude extracts were stored in sealed vials at $4{ }^{\circ} \mathrm{C}$ until further use.

\section{Standard chemicals used}

Gallic acid, catechol, $p$-hydroxy benzoic acid, caffeine, vanillic acid, caffeic acid, syringic acid, vanillin, $p$-coumaric acid, ferulic acid, ellagic acid, benzoic acid, $o$-coumaric acid, salicylic acid, and cinnamic acid were used as the standard compounds for the phenolics/caffeine, and rutin, myricetin, quercetin, naringenin, kaempferol, and apigenin were used for flavonoid compounds. All the chemical compounds were provided from Sigma-Aldrich (Darmstadt, Germany), and the analyses were performed at FSQC Laboratory (Cairo University, Faculty of Agriculture, Giza, Egypt).

Preparation of wood blocks

Pinus roxburghii wood blocks with dimensions of $1 \times 1 \times 0.5 \mathrm{~cm}^{3}$ were prepared at the Department of Forestry and Wood Technology, Alexandria University (Alexandria, Egypt). The blocks were autoclaved at $121{ }^{\circ} \mathrm{C}$ for $20 \mathrm{~min}$ and then cooled.

\section{Methods}

Analytical HPLC of phenolic/caffeine and flavonoid compounds

Phenolic/caffeine-type compounds were identified using an Agilent 1260 Infinity (Agilent Technologies, Santa Clara, CA, USA) HPLC series (Agilent Technologies, Santa Clara, CA, USA), equipped with a Quaternary pump and a Zorbax Eclipse plus C18 column (100 mm × $4.6 \mathrm{~mm}$ i.d.). An HPLC Smartline (Knauer, Berlin, Germany) equipped with a binary pump and a Zorbax Eclipse plus C18 (column $150 \mathrm{~mm} \times 4.6 \mathrm{~mm}$ i.d.) (Agilent Technologies, Santa Clara, CA, USA) was used for identifying flavonoid compounds. The 
conditions used to operate the apparatus can be found in the authors' previous published works (Al-Huqail et al. 2019; Behiry et al. 2019b; Salem et al. 2019b).

\section{Antifungal Activities of Pinus roxburghii Wood Treated with Leaf Extracts}

Isolation of the root rot and grey mold pathogens

Fungal pathogens isolated from infected plant samples were retrieved from the most vital strawberry-producing region in the district of Bader, Behiera Governorate, Egypt. The strawberry root and fruit tissues that were symptomatic parts of root rot and grey mold fungus were isolated on potato dextrose agar (PDA) medium. The resultant cultures were purified using single spore culture or hyphal tip techniques (Dhingra and Sinclair 1985). The fungal isolates were transferred to slant tubes containing PDA medium and were incubated for one week at room temperature. The pure cultures were examined microscopically, and they were morphologically identified at the Agricultural Botany Department, Faculty of Agriculture Saba Basha, and Plant Pathology Department, Faculty of Agriculture, Alexandria University, Alexandria, Egypt. Samples were further molecularly identified.

Identification of tested fungi through internal transcribed spacers (ITS) gene sequencing

Isolates were grown for one week on PDA at $25^{\circ} \mathrm{C}$. Total DNA was extracted from fresh mycelia using the QIAquick PCR purification Kit (QIAGEN, Manchester, England). Amplicons of the internal transcribed spacer region of the rDNA (ITS genes) were generated using ITS1/ITS4 primers and were sequenced (White et al. 1999; Geiser et al. 2004). Forward sequences were assembled at Macrogen Co., Seoul, Korea, and were then accessioned and deposited in GenBank.

\section{Antifungal activity tests}

Extracts were dissolved in $10 \%$ dimethyl sulfoxide (DMSO, Sigma-Aldrich, Darmstadt, Germany) and were prepared at concentrations of $1 \%, 2 \%$, and $3 \%$ solutions. The antifungal activities of $C$. uvifera leaf extracts (aqueous, acetone, and ethanol extracts) were assayed against the growth of the three isolated phytopathogenic fungi (Rhizoctonia solani, Fusarium culmorum, and Botrytis cinerea). Wood samples of Pinus roxburghii were treated with different concentrations $(1 \%, 2 \%$, and $3 \%)$ of the various $C$. uvifera leaf extracts. Three wood samples were used to treat with each fungus (Mansour and Salem 2015), and each wood sample received approximately $100 \mu \mathrm{L}$ of the concentrated extracts (Salem et al. 2019a). The wood samples treated with 10\% DMSO were used as a negative control.

Treated wood samples were placed directly on PDA medium in petri dishes inoculated with 5-mm diameter discs of 15-day-old PDA culture from each fungus. The petri dishes were incubated for one week at $25 \pm 1{ }^{\circ} \mathrm{C}$. The linear fungal growth was measured and compared to control treatments using the margin around the wood samples with no fungal growth (Povi et al. 2015; Mansour et al. 2015; Salem et al. 2016a,b, and 2019b). Mycelial growth inhibition (\%) was calculated using Eq. 1,

$$
\text { Mycelial growth inhibition }(\%)=\left(\frac{A 0-A t}{A 0}\right) \times 100
$$

where $A_{0}$ and $A_{\mathrm{t}}$ are the average diameters $(\mathrm{mm})$ of fungal colonies under the control and experimental treatments, respectively. 
Antibacterial activity assays

Six plant pathogenic bacteria were provided by the Bacterial Plant Diseases Laboratory, Plant Pathology Department, Faculty of Agriculture, Alexandria University, Alexandria, Egypt. The bacterial strains Agrobacterium tumefaciens (MG706145), Erwinia amylovora (HG423347), Ralstonia solanacearum (GH425351), Pectobacterium carotovorum subsp. carotovorum (HF674984), Pectobacterium atrosepticum (MG706146), and Dickeya solani (HF569035) were previously identified using the 16S rRNA gene, and were deposited into GenBank under the accession numbers listed above (Ashmawy 2015b; Salem et al. 2018). These bacterial strains were used to evaluate the antibacterial activities of $C$. uvifera leaf extracts.

The antibacterial activities of aqueous, acetone, or ethanol $C$. uvifera leaf extracts were assayed using the agar disk diffusion method (Kiehlbauch et al. 2000). Extracts with concentrations of $50,125,250,500,1250$, and $2500 \mu \mathrm{g} / \mathrm{mL}$ were made by dissolving extracts in $10 \%$ DMSO, and three discs were used for each concentration. Each disc received $20 \mu \mathrm{L}$ of a concentrated extract, while discs also received $20 \mu \mathrm{L}$ of the solvent used (10\% DMSO) as negative controls. The antibacterial activities of the extracts were compared with positive controls of amoxicillin $(25 \mu \mathrm{g} / \mathrm{disc})$, chloramphenicol ( $30 \mu \mathrm{g} / \mathrm{disc})$, and tobramycin $(10 \mu \mathrm{g} / \mathrm{disc})$. All discs were placed directly onto the solid media plates that were inoculated with the bacterium suspension $\left(0.1 \mathrm{~mL}\right.$ of $\left.10^{8} \mathrm{CFU} / \mathrm{mL}\right)$ and were incubated at $30{ }^{\circ} \mathrm{C}$ for three days before comparisons were made. The inhibition zones around the treated discs were recorded in $\mathrm{mm}$.

\section{Statistical Analysis}

The mycelial growth inhibition percentages for fungi and the inhibition zones recorded for the studied bacterial phytopathogens were statistically analyzed using twoway analysis of variance (ANOVA) with SAS software (v.8.02, SAS Institute, Cary, NC, USA). Comparisons among means were compared against the negative and/or positive control treatments using least significant difference (LSD 0.05) test.

\section{RESULTS AND DISCUSSION}

\section{Phenolic and Flavonoid-type Compounds}

Table 1 lists the phenolic and flavonoid-type compounds identified in the aqueous, acetone, and ethanol extracts. In the aqueous extracts (Fig. 1 $\left.\mathrm{A}_{1}\right)$, the main identified phenolic compounds were benzoic acid, gallic acid, ellagic acid, caffeine, and $o$-coumaric acid. In the acetone extracts (Fig. 1B $\mathrm{B}_{1}$ ), the predominant phenolic compounds were benzoic acid, ellagic acid, gallic acid, o-coumaric acid, $p$-coumaric acid, caffeine, salicylic acid, and $p$-hydroxy benzoic acid. Finally, the primary phenolic compounds in the ethanol extracts (Fig. $1 \mathrm{C}_{1}$ ) were benzoic acid, ellagic acid, gallic acid, $o$-coumaric acid, and $p$ coumaric acid.

In terms of flavonoid-type compounds, all three extracts contained rutin (816 mg, $12054 \mathrm{mg}$, and $53061 \mathrm{mg}$, in $100 \mathrm{~g}$ of aqueous, acetone, and ethanol extracts, respectively), myricetin (489 mg, $1753 \mathrm{mg}$, and $10271 \mathrm{mg}$, in $100 \mathrm{~g}$ of aqueous, acetone, and ethanol extracts, respectively), and quercetin (41.9 mg, $118 \mathrm{mg}$, and $477 \mathrm{mg}$ in $100 \mathrm{~g}$ of aqueous, acetone, and ethanol extracts, respectively). The flavonoid compounds found in aqueous, acetone, and ethanol extracts are summarized in Figs. $1 \mathrm{~A}_{2}, 1 \mathrm{~B}_{2}$, and $1 \mathrm{C}_{2}$, respectively. 
The above results showed that ethanol extracts contained the greatest amounts of gallic acid, ellagic acid, hydrolysable tannin, and flavonoid-types of compounds. In contrast, benzoic acid was observed in the highest quantities in acetone extracts, followed by ethanol extracts.

Table 1. HPLC Chemical Composition Analysis of Phenolic and Flavonoid Compounds in Aqueous, Acetone, and Ethanol C. uvifera Leaf Extracts

\begin{tabular}{|c|c|c|c|}
\hline \multirow[t]{2}{*}{ Compound } & \multicolumn{3}{|c|}{ Extract $(\mathrm{mg} / 100 \mathrm{~g})$} \\
\hline & Aqueous & Acetone & Ethanol \\
\hline \multicolumn{4}{|c|}{ Phenolic/Caffeine } \\
\hline Gallic acid & 90.68 & 139.68 & 213.30 \\
\hline Catechol & 17.61 & 19.82 & 22.65 \\
\hline$p$-Hydroxy benzoic acid & 18.74 & 33.73 & 26.55 \\
\hline Caffeine & 32.96 & 41.07 & 15.32 \\
\hline Vanillic acid & 3.69 & ND & 7.94 \\
\hline Caffeic acid & 2.49 & ND & ND \\
\hline Syringic acid & 5.27 & 6.80 & 6.58 \\
\hline Vanillin & 16.01 & 10.80 & 15.88 \\
\hline$p$-Coumaric acid & 5.84 & 43.19 & 33.76 \\
\hline Ferulic acid & 2.71 & 38.87 & 28.65 \\
\hline Ellagic acid & 89.27 & 322.51 & 327.25 \\
\hline Benzoic acid & 180.39 & 777.16 & 694.16 \\
\hline o-Coumaric acid & 20.77 & 70.34 & 66.09 \\
\hline Salicylic acid & 14.39 & 36.57 & 32.27 \\
\hline Cinnamic acid & ND & ND & ND \\
\hline \multicolumn{4}{|c|}{ Flavonoid } \\
\hline Rutin & 816.66 & 12054.91 & 53061.54 \\
\hline Myricetin & 489.14 & 1753.72 & 10271.96 \\
\hline Quercetin & 41.87 & 118.22 & 476.88 \\
\hline Naringenin & ND & ND & ND \\
\hline Kaempferol & ND & ND & ND \\
\hline Apigenin & ND & ND & ND \\
\hline
\end{tabular}

ND: Not determined 


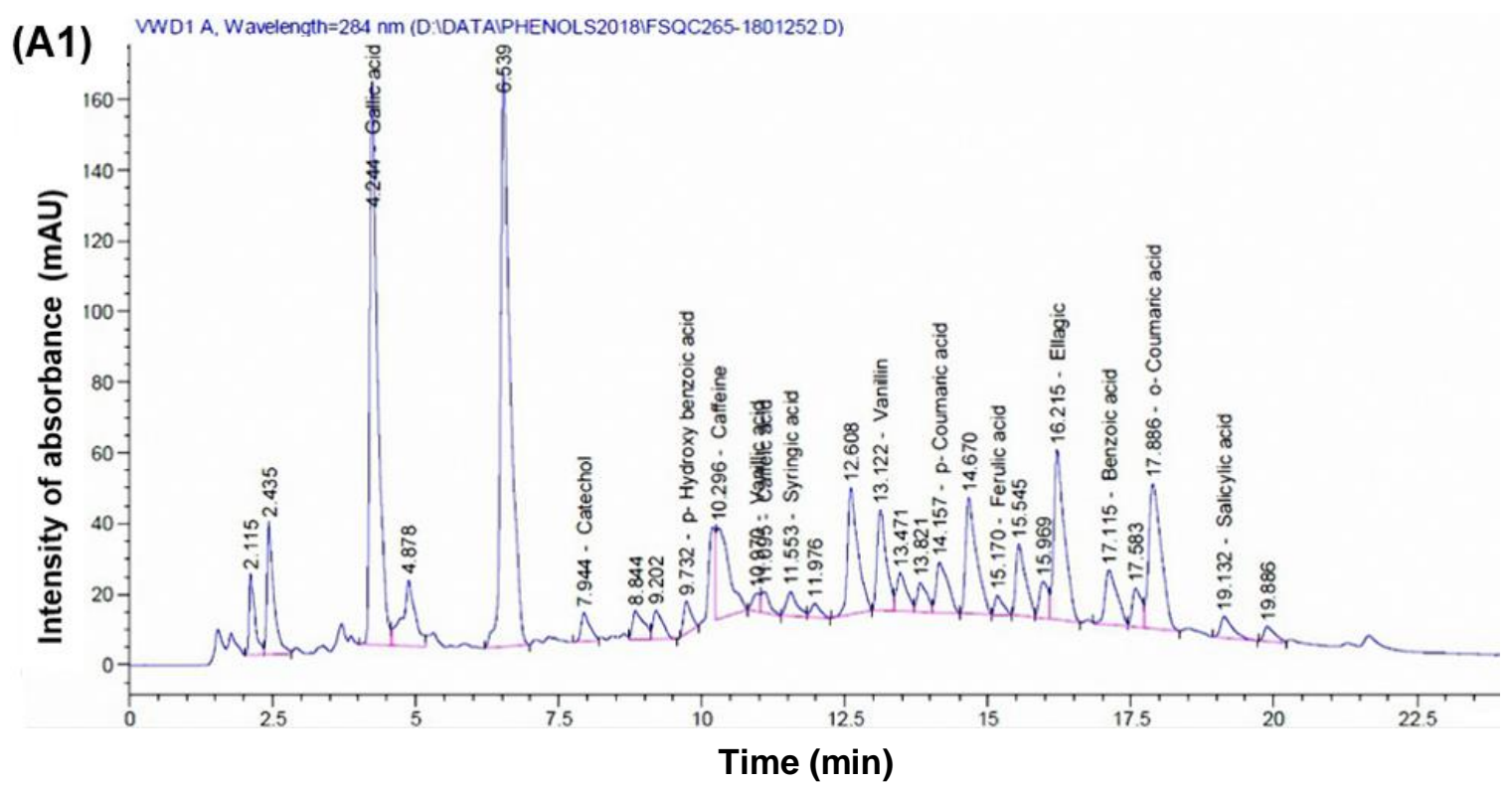

(A2)

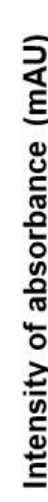

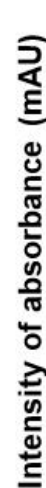
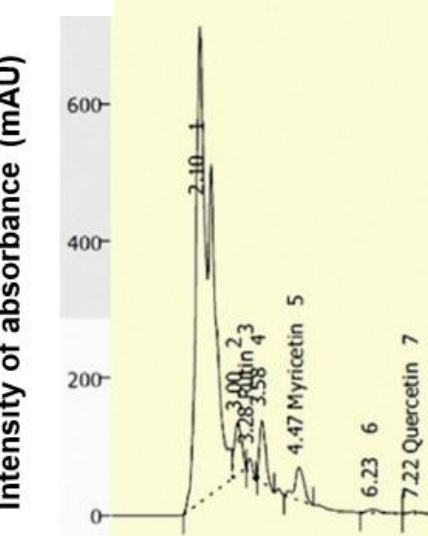

's

10

(B1)

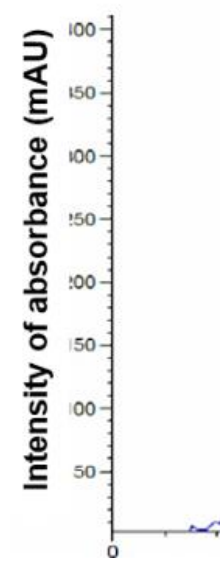

\section{Time (min)}

— I:IResults IFSQCI FlavonoidsIFSQC265-2018

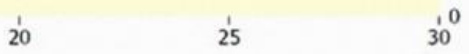


(B2)

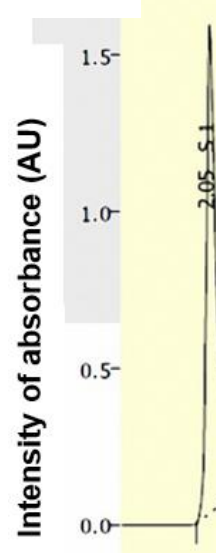

0
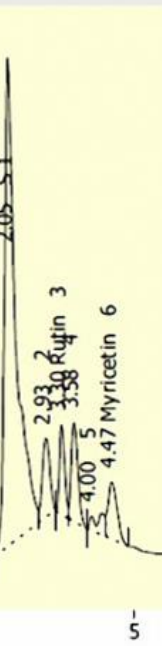

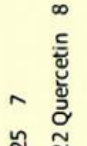

幽

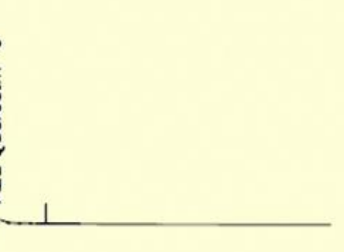

10

is

20

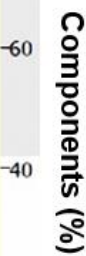

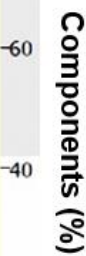

$-80$

$-20$

Time (min)
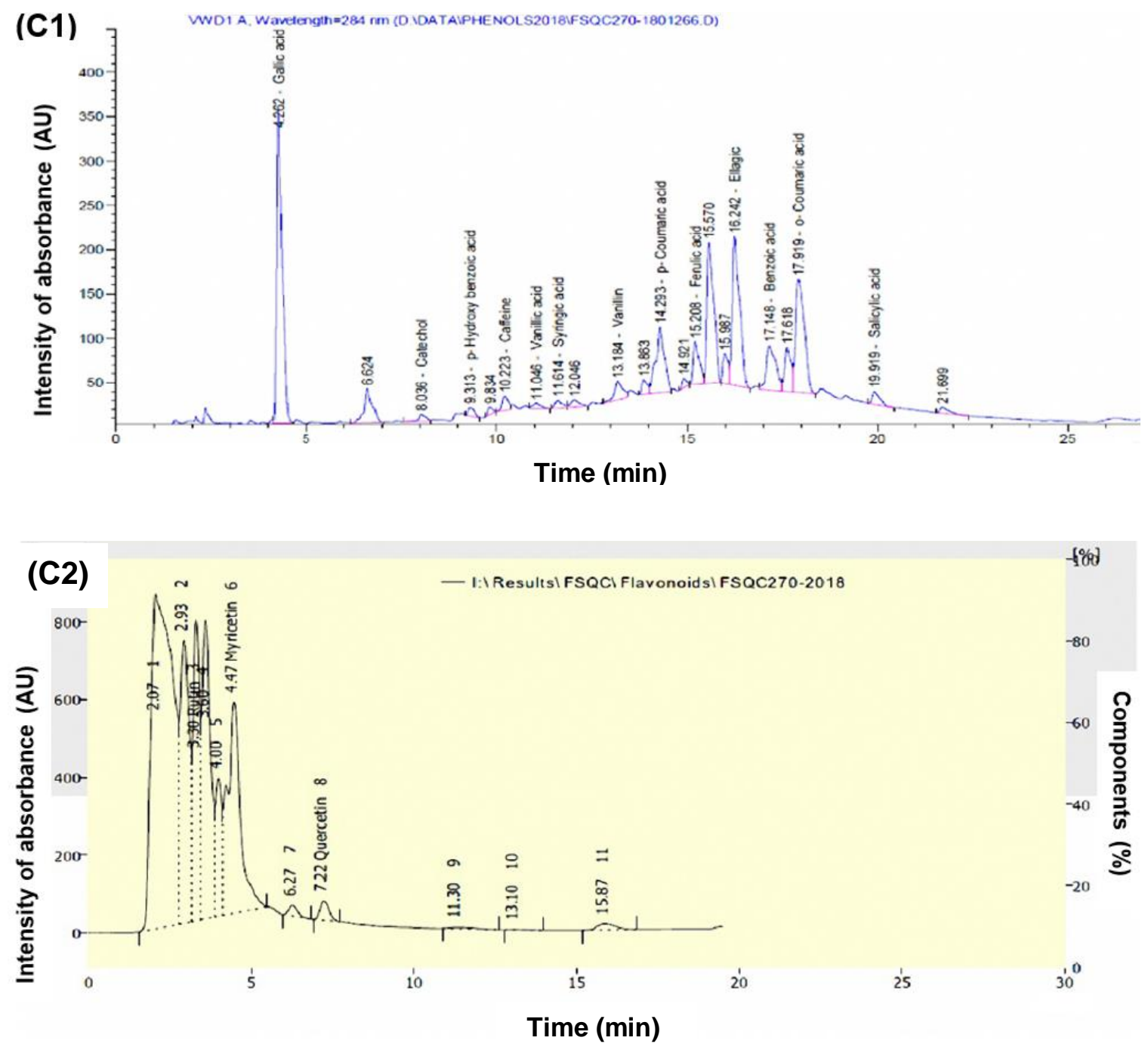

Fig. 1. HPLC chromatograms of $C$. uvifera leaf extracts: $A_{1}, B_{1}$, and $C_{1}$ are phenolic compounds and $A_{2}, B_{2}$, and $C_{2}$ are flavonoid compounds from aqueous, acetone, and ethanol extracts, respectively. 


\section{Antifungal Activity}

Isolation and initial identification

Three fungal isolates were recovered from infected strawberry plants using the methodology outlined in the 'Materials' and 'Methods' sections. Cultures that possessed typical morphological characteristics of $F$. culmorum, $R$. solani, and B. cinerea were purified.

\section{ITS identification}

The rDNA regions of the ITS were amplified and sequenced for all fungal isolates. The nucleotide sequences blasted in NCBI confirmed that the three isolates were identical to the initial identifications of $F$. culmorum, $R$. solani, and B. cinerea. The sequences were deposited in GenBank under accession numbers MN398395, MN398397, and MN398399, respectively.

\section{Antifungal activity and bioactivity of extracts}

Table 2 shows the mycelial growth inhibition (MGI\%) for R. solani, Botrytis cinerea, and $F$. culmorum caused by wood treated with aqueous, acetone, and ethanol $C$. uvifera extracts at concentrations of $1 \%, 2 \%$, and $3 \%$ levels.

Ethanol extracts at $3 \%, 2 \%$, and $1 \%$ concentrations indicated the greatest growth inhibition of $R$. solani, with MGIs of $64.4 \%, 61.8 \%$, and $58.1 \%$, respectively. This was followed by acetone extracts at 3\% and 2\%, with MGIs of $52.2 \%$ and $49.2 \%$, respectively. Furthermore, inhibition of $43.7 \%$ was achieved by aqueous extract applied to wood at a concentration of $3 \%$.

Complete inhibition (MGI 100\%) of B. cinerea growth was achieved using wood treated with $3 \%$ ethanol extract, when compared to concentrations of $2 \%$ and $1 \%$ that achieved only some inhibition (MGIs of $61.8 \%$ and $58.1 \%$, respectively). Wood treated with $2 \%$ and $1 \%$ acetone extracts reached MGI values of $52.2 \%$ and $49.2 \%$ against the growth of $B$. cinerea, respectively, while $43.7 \%$ inhibition was reached by aqueous extracts applied to wood at $3 \%$.

Ethanol extracts at concentrations of $3 \%$ and $2 \%$ accomplished MGI values of $38.5 \%$ and $38.1 \%$, respectively, while acetone extracts at concentrations of $3 \%$ and $2 \%$ achieved $27.8 \%$ and $24.1 \%$ inhibition of $F$. culmorum growth, respectively. 
Table 2. Antifungal Activities of Wood Treated with $C$. uvifera Leaf Extracts

\begin{tabular}{|c|c|c|c|c|c|}
\hline \multicolumn{2}{|c|}{ Treatments } & \multirow{3}{*}{$\begin{array}{c}\text { Concentration } \\
(\%)\end{array}$} & \multicolumn{3}{|c|}{ 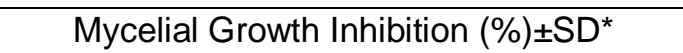 } \\
\hline & & & $\begin{array}{c}\text { Rhizoctonia } \\
\text { solani }\end{array}$ & $\begin{array}{l}\text { Botrytis } \\
\text { cinerea }\end{array}$ & $\begin{array}{l}\text { Fusarium } \\
\text { culmorum }\end{array}$ \\
\hline & Control & & $0.00 \pm 0.00$ & $0.00 \pm 0.00$ & $0.00 \pm 0.00$ \\
\hline \multirow[t]{9}{*}{$\begin{array}{l}\text { C. uvifera Leaf } \\
\text { Extracts }\end{array}$} & \multirow{3}{*}{ Aqueous } & $1 \%$ & $35.18 \pm 0.64$ & $\begin{array}{c}31.85 \pm \\
1.69\end{array}$ & $0.00 \pm 0.00$ \\
\hline & & $2 \%$ & $36.29 \pm 0.64$ & $\begin{array}{c}36.66 \pm \\
0.00\end{array}$ & $0.00 \pm 0.00$ \\
\hline & & $3 \%$ & $43.71 \pm 1.28$ & $\begin{array}{c}38.14 \pm \\
1.28\end{array}$ & $0.00 \pm 0.00$ \\
\hline & \multirow{3}{*}{ Acetone } & $1 \%$ & $35.92 \pm 1.28$ & $\begin{array}{c}37.77 \pm \\
1.92\end{array}$ & $0.00 \pm 0.00$ \\
\hline & & $2 \%$ & $49.25 \pm 1.28$ & $\begin{array}{c}38.88 \pm \\
2.22\end{array}$ & $24.07 \pm 0.64$ \\
\hline & & $3 \%$ & $52.22 \pm 0.00$ & $\begin{array}{c}54.07 \pm \\
0.64\end{array}$ & $27.77 \pm 1.11$ \\
\hline & \multirow[t]{3}{*}{ Ethanol } & $1 \%$ & $58.14 \pm 0.64$ & $\begin{array}{c}53.33 \pm \\
0.00\end{array}$ & $0.00 \pm 0.00$ \\
\hline & & $2 \%$ & $61.85 \pm 0.64$ & $\begin{array}{c}70.37 \pm \\
6.11 \\
\end{array}$ & $38.14 \pm 1.28$ \\
\hline & & $3 \%$ & $64.44 \pm 0.00$ & $100 \pm 0.00$ & $38.51 \pm 0.64$ \\
\hline & P-value & & 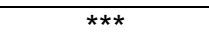 & 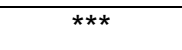 & 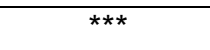 \\
\hline
\end{tabular}

${ }^{*} \mathrm{SD}$, standard deviation

(A)
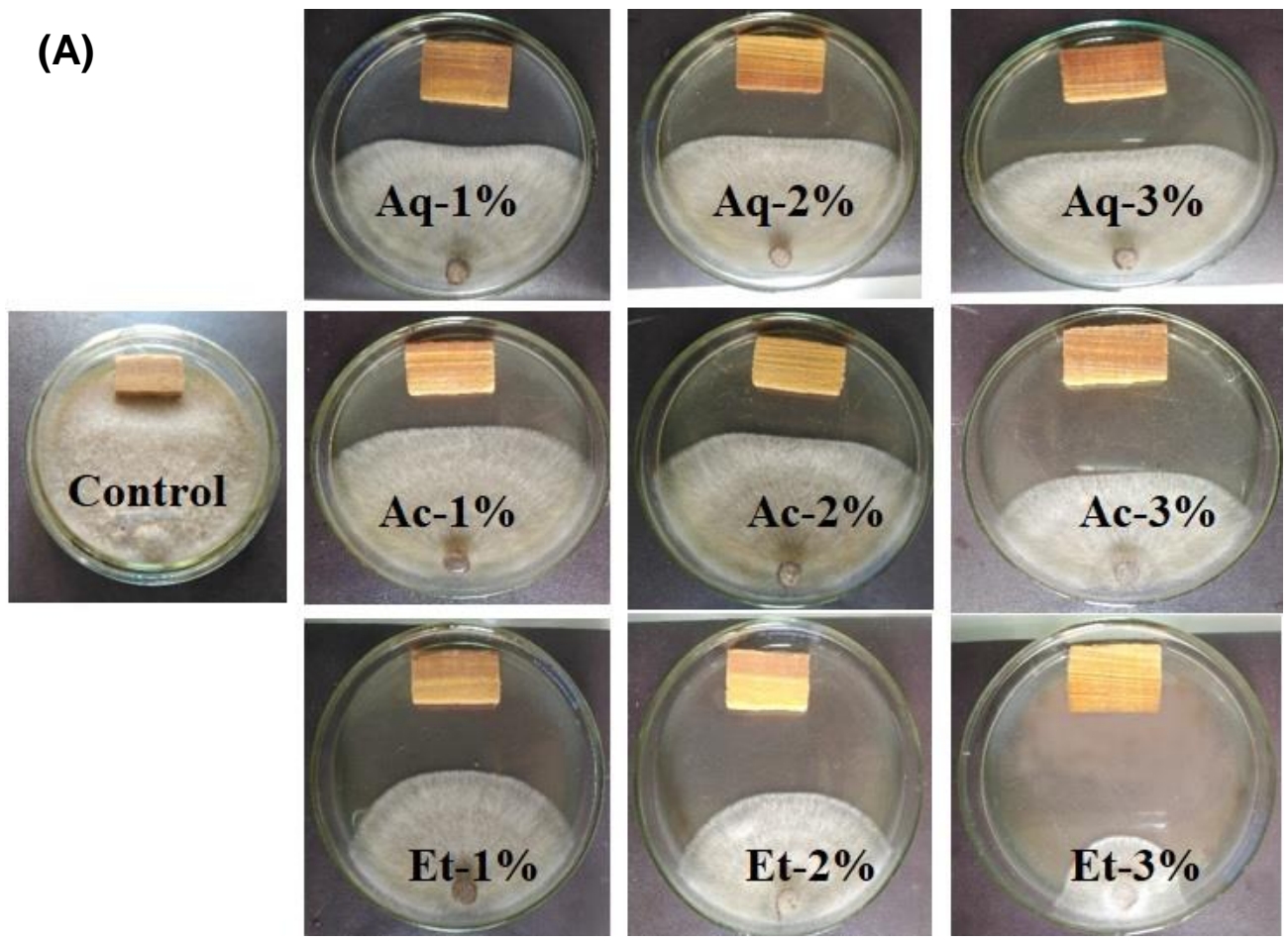


\section{(B)}
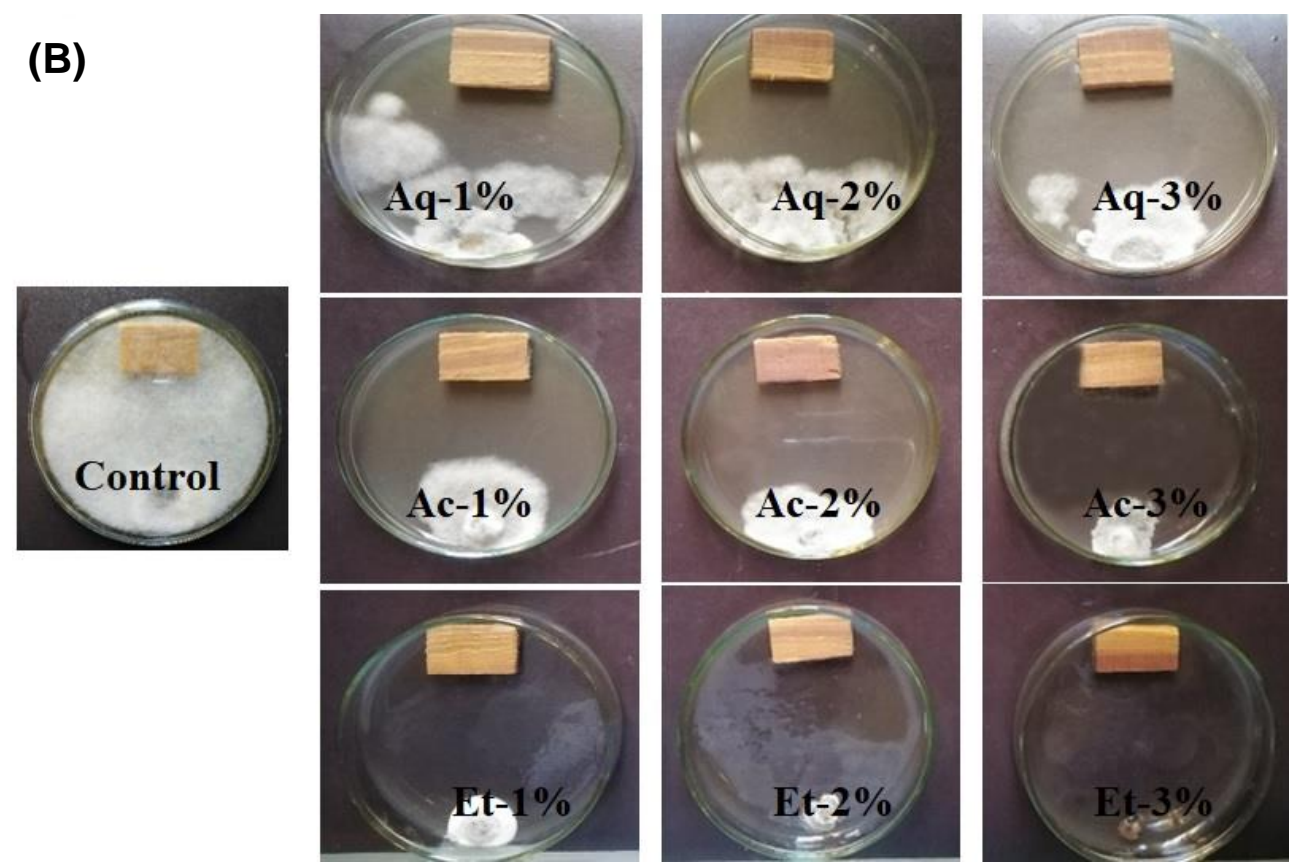

(C)
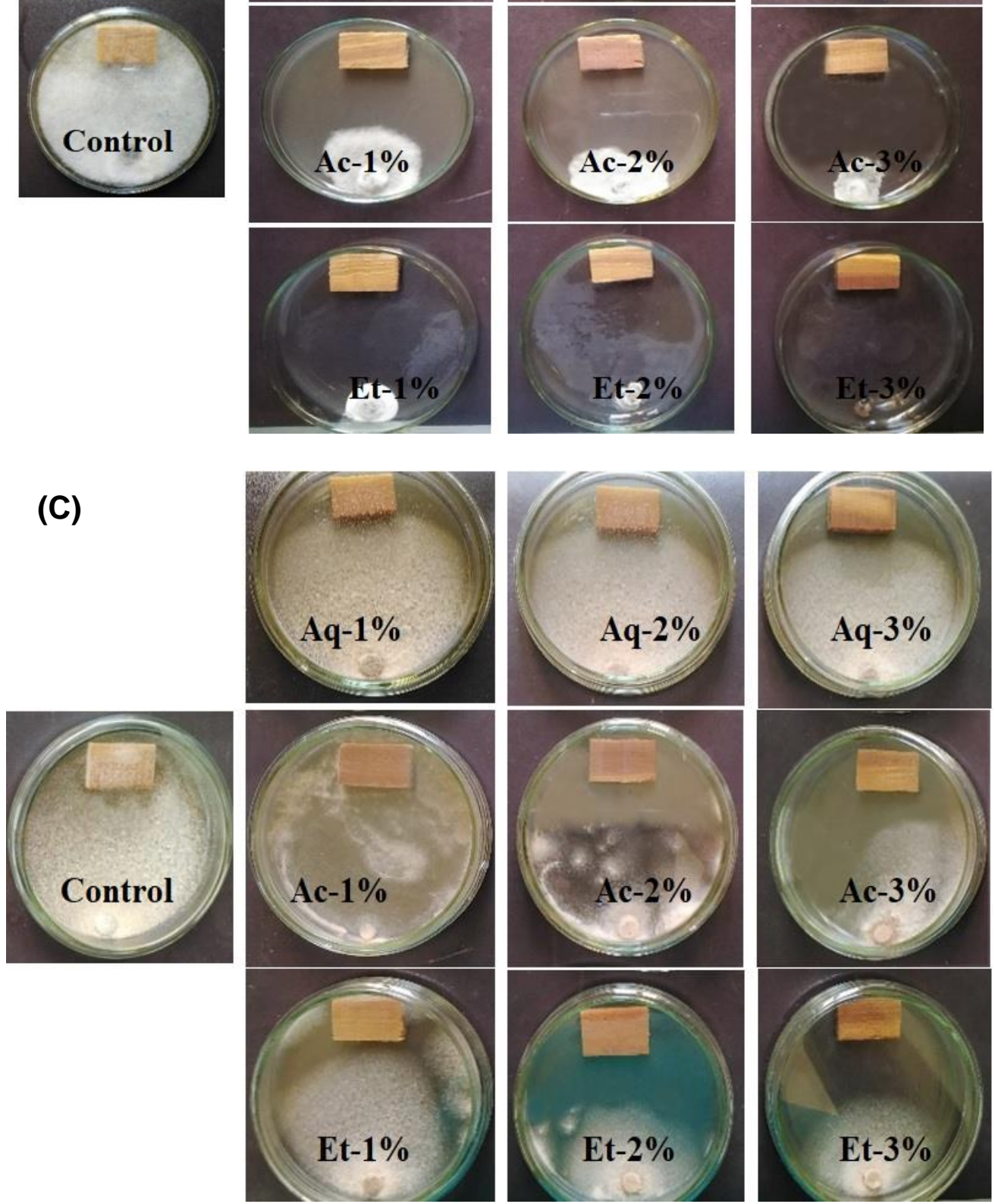

Fig. 2. Antifungal activities of wood treated with aqueous (Aq), acetone (Ac), and ethanol (Et) $C$. uvifera leaf extracts vs. Rhizoctonia solani (A), Botrytis cinerea (B), and Fusarium culmorum (C) 
Antibacterial activities of extracts

Table 3 presents the antibacterial activities of $C$. uvifera extracts against the growth of six phytopathogenic bacteria. Acetone extracts were moderately active against $R$. solanacearum, with an inhibition zone of $10 \mathrm{~mm}$ at the concentrations of $250 \mu \mathrm{g} / \mathrm{mL}, 500$ $\mu \mathrm{g} / \mathrm{mL}, 1250 \mu \mathrm{g} / \mathrm{mL}$, and $2500 \mu \mathrm{g} / \mathrm{mL}$, while the chloramphenicol positive control (30 $\mu \mathrm{g} / \mathrm{disc}$ ) reached an inhibition zone (IZ) of $28.8 \mathrm{~mm}$. Ethanol extract at $2500 \mu \mathrm{g} / \mathrm{mL}$ achieved an IZ value of $14.0 \mathrm{~mm}$ against the growth of Erwinia amylovora, while the positive control (Chloramphenicol $30 \mu \mathrm{g} / \mathrm{disc}$ ) reached an IZ of $26.7 \mathrm{~mm}$. Acetone and ethanol extracts at $2500 \mu \mathrm{g} / \mathrm{mL}$ observed IZ values of $10 \mathrm{~mm}$ against the growth of Dickeya solani, compared to $20 \mathrm{~mm}$ for the positive control (Chloramphenicol $30 \mu \mathrm{g} / \mathrm{disc}$ ). At 2500 $\mu \mathrm{g} / \mathrm{mL}$, acetone and ethanol extracts showed IZ values of $12 \mathrm{~mm}$ against the growth of Pectobacterium carotovorum subsp. carotovorum; whilst the amoxicillin, chloramphenicol, and tobramycin positive controls produced IZ values of $15.3 \mathrm{~mm}, 19.3$ $\mathrm{mm}$, and $15.0 \mathrm{~mm}$, respectively. Aqueous extract at $2500 \mu \mathrm{g} / \mathrm{mL}$ reached an IZ value of $10.00 \mathrm{~mm}$ against Pectobacterium atrosepticum, while other extracts with their concentrations indicated only weak activity, with inhibition zones that ranged from $6.0 \mathrm{~mm}$ to $8 \mathrm{~mm}$. The positive controls of amoxicillin, chloramphenicol, and tobramycin reached IZ values of $10.0 \mathrm{~mm}, 12.3 \mathrm{~mm}$, and $15.0 \mathrm{~mm}$, respectively. Ethanol extracts at 1250 $\mu \mathrm{g} / \mathrm{mL}$ and $2500 \mu \mathrm{g} / \mathrm{mL}$ showed IZ values of $11.0 \mathrm{~mm}$ and $12.0 \mathrm{~mm}$, respectively, against the growth of Agrobacterium tumefaciens, while the amoxicillin, chloramphenicol, and tobramycin positive controls produced IZ values of $5.0 \mathrm{~mm}, 8.3 \mathrm{~mm}$, and $13.7 \mathrm{~mm}$. 
Table 3. Antibacterial Activities of Extracts from Leaves of C. uvifera

\begin{tabular}{|c|c|c|c|c|c|c|c|}
\hline \multirow[t]{2}{*}{ Tested Material } & \multirow{2}{*}{$\begin{array}{l}\text { Concentration } \\
(\mu \mathrm{g} / \mathrm{mL})\end{array}$} & \multicolumn{6}{|c|}{ Inhibition zone (Diameter $\pm \mathrm{SD}^{\star}$ ) } \\
\hline & & $\begin{array}{c}\text { Ralstonia } \\
\text { solanacearum }\end{array}$ & $\begin{array}{l}\text { Erwinia } \\
\text { amylovora }\end{array}$ & $\begin{array}{l}\text { Dickeya } \\
\text { solani }\end{array}$ & $\begin{array}{l}\text { Pectobacterium } \\
\text { carotovorum } \\
\text { subsp. } \\
\text { carotovorum } \\
\end{array}$ & $\begin{array}{l}\text { Pectobacterium } \\
\text { atrosepticum }\end{array}$ & $\begin{array}{c}\text { Agrobacterium } \\
\text { tumefaciens }\end{array}$ \\
\hline Negative control & 0 & $0.00 \pm 0.00$ & $0.00 \pm 0.00$ & $0.00 \pm 0.00$ & $0.00 \pm 0.00$ & $0.00 \pm 0.00$ & $0.00 \pm 0.00$ \\
\hline \multirow{6}{*}{ Aqueous extract } & 50 & $7.00 \pm 2.00$ & $7.00 \pm 1.00$ & $8.00 \pm 1.00$ & $7.00 \pm 1.00$ & $6.00 \pm 0.00$ & $7.00 \pm 0.00$ \\
\hline & 125 & $8.00 \pm 2.00$ & $8.00 \pm 0.00$ & $8.00 \pm 1.00$ & $7.00 \pm 0.00$ & $7.00 \pm 0.00$ & $8.00 \pm .00$ \\
\hline & 250 & $8.00 \pm 1.00$ & $8.00 \pm 0.00$ & $9.00 \pm 2.00$ & $7.00 \pm 0.00$ & $7.00 \pm 0.00$ & $9.00 \pm 0.00$ \\
\hline & 500 & $8.00 \pm 1.00$ & $9.00 \pm 1.00$ & $9.00 \pm 1.00$ & $8.00 \pm 0.00$ & $7.00 \pm 0.00$ & $9.00 \pm 0.00$ \\
\hline & 1250 & $9.00 \pm 1.00$ & $9.00 \pm 0.00$ & $9.00 \pm 1.00$ & $10.00 \pm 1.00$ & $7.00 \pm 1.00$ & $8.00 \pm 1.00$ \\
\hline & 2500 & $9.00 \pm 0.00$ & $8.00 \pm 1.00$ & $9.00 \pm 1.00$ & $10.00 \pm 1.00$ & $10.00 \pm 1.00$ & $10.00 \pm 1.00$ \\
\hline \multirow{6}{*}{ Acetone extract } & 50 & $8.00 \pm 2.00$ & $8.00 \pm 1.00$ & $6.00 \pm 0.00$ & $8.00 \pm 1.00$ & $7.00 \pm 1.73$ & $6.00 \pm 1.00$ \\
\hline & 125 & $9.00 \pm 1.00$ & $8.00 \pm 1.00$ & $7.00 \pm 0.00$ & $10.00 \pm 0.00$ & $7.00 \pm 1.00$ & $7.00 \pm 1.00$ \\
\hline & 250 & $10.00 \pm 0.00$ & $8.00 \pm 1.00$ & $8.00 \pm 0.00$ & $10.00 \pm 1.00$ & $7.00 \pm 1.00$ & $8.00 \pm 1.00$ \\
\hline & 500 & $10.00 \pm 1.00$ & $9.00 \pm 1.00$ & $8.00 \pm 0.00$ & $10.00 \pm 1.00$ & $8.00 \pm 0.00$ & $8.33 \pm 1.52$ \\
\hline & 1250 & $10.00 \pm 1.00$ & $10.00 \pm 1.00$ & $8.00 \pm 1.00$ & $10.00 \pm 0.00$ & $8.00 \pm 1.00$ & $8.00 \pm 1.00$ \\
\hline & 2500 & $10.00 \pm 0.00$ & $10.00 \pm 1.00$ & $10.00 \pm 0.00$ & $12.00 \pm 0.00$ & $8.00 \pm 1.00$ & $8.00 \pm 1.00$ \\
\hline \multirow{6}{*}{ Ethanol extract } & 50 & $7.00 \pm 0.00$ & $8.00 \pm 1.00$ & $8.00 \pm 1.00$ & $8.00 \pm 1.00$ & $7.00 \pm 1.73$ & $9.00 \pm 1.00$ \\
\hline & 125 & $8.00 \pm 0.00$ & $9.00 \pm 1.00$ & $8.00 \pm 0.00$ & $8.00 \pm 0.00$ & $7.00 \pm 0.00$ & $9.00 \pm 1.00$ \\
\hline & 250 & $9.00 \pm 1.00$ & $10.00 \pm 0.00$ & $9.00 \pm 1.00$ & $8.00 \pm 0.00$ & $8.00 \pm 0.00$ & $10.00 \pm 0.00$ \\
\hline & 500 & $9.00 \pm 1.00$ & $9.00 \pm 0.00$ & $9.00 \pm 1.00$ & $9.00 \pm 0.00$ & $8.00 \pm 1.00$ & $10.00 \pm 2.00$ \\
\hline & 1250 & $9.00 \pm 1.00$ & $10.00 \pm 2.00$ & $9.00 \pm 0.00$ & $10.00 \pm 1.00$ & $8.00 \pm 1.00$ & $11.00 \pm 1.00$ \\
\hline & 2500 & $9.00 \pm 0.00$ & $14.00 \pm 0.00$ & $10.00 \pm 1.00$ & $12.00 \pm 2.00$ & $8.00 \pm 0.00$ & $12.00 \pm 1.00$ \\
\hline \multicolumn{8}{|c|}{ Positive Controls (Antibiotics) } \\
\hline Amoxicillin & $25 \mu \mathrm{g} / \mathrm{disc}$ & $6.00 \pm 0.50$ & $7.00 \pm 0.50$ & $5.33 \pm 0.50$ & $15.33 \pm 0.86$ & $7.00 \pm 0.50$ & $5.00 \pm 0.00$ \\
\hline Chloramphenicol & $30 \mu \mathrm{g} / \mathrm{disc}$ & $28.77 \pm 1.48$ & $26.66 \pm 2.54$ & $20.00 \pm 0.71$ & $19.33 \pm 0.86$ & $12.33 \pm 0.86$ & $8.33 \pm 0.86$ \\
\hline Tobramycin & $10 \mu \mathrm{g} / \mathrm{disc}$ & $10.00 \pm 1.00$ & $5.33 \pm 0.50$ & $5.00 \pm 0.00$ & $15.00 \pm 0.50$ & $15.00 \pm 0.50$ & $13.66 \pm 0.86$ \\
\hline P-value & & ** & ** & k夫 & ** & ** & ** \\
\hline
\end{tabular}

${ }^{\star}$ SD, standard deviation; ** Highly significant at 0.01 level of probability 
Aqueous, acetone, and ethanol extracts from $C$. uvifera leaves grown in Egypt produced strong antifungal activities against three phytopathogenic fungi (Rhizoctonia solani, Fusarium culmorum, and Botrytis cinerea) when applied to wood samples of Pinus roxburghii. Moderate activity was found against the growth of six phytopathogenic bacteria (Agrobacterium tumefaciens, Erwinia amylovora, Ralstonia solanacearum, Pectobacterium carotovorum subsp. carotovorum, Pectobacterium atrosepticum, and Dickeya solani). Furthermore, the extracts contained different compounds related to phenolic and flavonoid constituents.

Various phenolic and flavonoid types of compounds were identified in aqueous, acetone, and ethanol extracts of leaves from $C$. uvifera using HPLC analysis. Previously, aqueous extracts of $C$. uvifera leaves had total phenol and flavonoid contents of $346.15 \pm$ $9.65(\mu \mathrm{g}$ gallic acid equivalent $(\mathrm{GAE}) / \mathrm{mL})$, and $360.44 \pm 0.89(\mu \mathrm{g}$ catechin equivalent $\mathrm{CE} / \mathrm{mL})$, respectively, and exhibited weak antifungal activities against Alternaria alternate, Fusarium oxysporum, $F$. verticillioides, Colletotrichum gloeosporioides, and $C$. capsici (Rodríguez-García et al. 2019).

The antimicrobial activities observed in this study may have been due to the presence of phenolic and flavonoid types of compounds. Various medicinal plants containing phenolic and flavonoids in their different extracts have been reported to possess antimicrobial activities (Rahman and Moon 2007; Vaquero et al. 2007; Ayaz et al. 2008; Hendra et al. 2011; Al-Huqail et al. 2019; Behiry et al. 2019b).

Previous studies by the authors gave promising information on the antibacterial and antifungal activities of soaking wood blocks with plant extracts. For instance, in the study of Al-Huqail et al. (2019) it was found that the high content of the phenolic and flavonoids, quercetin, benzoic acid, naringenin, caffeine, o-coumaric acid, and kaempferol in Acacia saligna flowers extract exhibited bioactivities against $F$. culmorum, Rhizoctonia solani, and Penicillium chrysogenum and several bacterial strains. Also, the peel extracts of Musa paradisiaca L. contained gallic acid, naringenin, rutin, ellagic acid, and myricetin compounds which presented antimicrobial activity against the fungal isolates $R$. solani and F. culmorum, and the bacterial isolate A. tumefaciens (Behiry et al. 2019b). According to the HPLC analysis of Withania somnifera fruits acetone extract, the most abundant quantified phenolic and flavonoid compounds are salicylic acid, vanillic acid, rutin, and myricetin. As a result, the applied concentrations of the extract at $2 \%$ and $3 \%$ totally inhibited the growth of A. tumefaciens, E. amylovora, and Pseudomonas cichorii bacteria and the concentration $3 \%$ caused fungal inhibition of $F$. culmorum and $R$. solani (EL-Hefny et al. 2020).

Gallic acid, caffeic acid, vanillic acid, rutin, and quercetin have been isolated from various wines and have exhibited strong antimicrobial properties against pathogenic microorganisms (Vaquero et al. 2007). Gallic and benzoic acids, as well as myricetin-3-Orhamnoside (a flavonoid compound), have been isolated from $C$. dugandiana leaves (Compagnone et al. 1995; Li et al. 1999). Compounds of simiarenol, sitostenone, sitosterol, trans-phytol, and vanillic acid have been isolated from the leaves and stem of C. mollis (Oliveira et al. 2008).

Gallic acid, a phenolic compound, isolated from $C$. uvifera seeds has been shown to possess antibacterial properties against Salmonella typhimurium and Escherichia coli (Moreno-Morales et al. 2008). In addition, the methanolic extracts of $C$. uvifera seeds contained compounds with antifungal activities against Candida albicans, Fusarium oxysporum, and Fusarium decencellulare (Moreno-Morales et al. 2008). Aqueous extracts of $C$. cozumelensis were found to express antibacterial activities against Staphylococcus 
aureus, Bacillus punullus, and Pseudomonas aeruginosa, while ethanol extracts of $C$. pubescens exhibited antimalarial activities (Coe and Anderson 1996).

To the best of the authors' knowledge, the present study is the first to evaluate the effects of $C$. uvifera leaf extracts on the growth of phytopathogenic bacteria. The moderate antibacterial activities of extracts from $C$. uvifera leaves observed in this study are consistent with the results of previous antibacterial evaluation trails using natural extracts. For example, alkaloidal extracts from Conocarpus lancifolius leaves are effective against A. tumefaciens and E. amylovora (Ali et al. 2013), while acetone and $n$-butanol extracts from Callistemon viminalis flowers, essential oils from the aerial parts of Conyza dioscoridis, and $n$-butanol extracts from the bark of Eucalyptus camaldulensis are all effective against A. tumefaciens (EL-Hefny et al. 2017b). Finally, essential oils or $n$ butanol fractions derived from cones of Pinus halepensis are effective against $D$. solani, $P$. atrosepticum, R. solanacearum, and A. tumefaciens (Ashmawy et al. 2018a).

Quercetin, a flavonoid compound, was found in all the extracts of $C$. uvifera leaves. Quercetin isolated from different plant extracts has been reported to have strong antifungal activities (Weidenbörner et al. 1990; Tempesti et al. 2012; Alves et al. 2014). For example, Terminalia brownii stem bark extract contained quercetin-7-O-diglucoside and demonstrated strong antifungal activities against some strains of Aspergillus and Fusarium (Salih et al. 2017), and dihydroquercetin isolated from barley suppressed the growth of Fusarium spp. (Mierziak et al. 2014).

Combinations of quercetin and morin, and quercetin and rutin, were more active as antibacterial agents than either flavonoid alone. While rutin has no antibacterial activities by itself, the antibacterial activities of quercetin and morin are enhanced in the presence of rutin against Salmonella enteritidis and Bacillus cereus (Arima et al. 2002). Quercetin and rutin are potentially effective as antifungal agents against Candida sp. and Cryptococcus neoformans strains (Oliveira et al. 2016).

The activities of ethanolic extracts from Morinda citrifolia fruit have been linked to the pure compounds of rutin and asperulosidic acid (Taechowisan et al. 2019). The antifungal activities of extracts from Duguetia furfuracea have been shown to be related to the presence of phenols and flavonoids such as caffeic acid, rutin, quercitrin, and isoquercitrin (Soares de Araújo Pinho et al. 2016). In addition, quercetin 3-O-methyl ether isolated from Cistus laurifolius leaves has antibacterial activities against Helicobacter pylori (Ustün et al. 2006), and quercetin-3-glucoside isolated from leaves of Scutellaria oblonga successfully kills Staphylococcus aureus (Rajendran et al. 2016). Naringin and quercetin have been found in the mesocarp and seed extracts of Phaleria macrocarpa and can have strong antifungal activities against Aspergillus niger (Hendra et al. 2011). Quercetin and kaempferol were identified in the bound flavonoids of Euphorbia hirta stem extracts, and have shown to be active against Aspergillus flavus, A. niger, Trichophyton mentagrophytes, and Candida albicans (Singh and Kumar 2013).

Myricetin has been shown to potentially possess antibacterial activities (Lopes et al. 2017). Myricetin and rutin were detected in the hydroalcoholic fractions of Chrysobalanus icaco extracts, and displayed potential antifungal activities against Candida albicans and C. parapsilosis (Silva et al. 2017). Therefore, C. uvifera leaf extract could be used as a source of phytochemical agent with potential antibacterial and antifungal activities. 


\section{CONCLUSIONS}

1. Phytochemicals extracted from C. uvifera leaves using water, acetone, and ethanol as solvents were evaluated for their antimicrobial activities against some phytopathogenic bacterial and fungal strains.

2. The extracts showed strong antifungal activities against $R$. solani, F. culmorum, and $B$. cinerea, when applied to wood samples of $P$. roxburghii. Moderate activity was observed against the growth bacteria A. tumefaciens, E. amylovora, $R$. solanacearum, $P$. carotovorum subsp. carotovorum, $P$. atrosepticum, and $D$. solani.

3. The HPLC analysis of the extracts showed the presence of various phenolic and flavonoid-type compounds, which exhibited the potential antimicrobial activity. It was concluded that $C$. uvifera leaves extracts are a good alternative source to phytochemicals for use as potential antifungal and antibacterial agents.

\section{ACKNOWLEDGMENTS}

The authors are grateful to the Deanship of Scientific Research, King Saud University, for funding through the Vice Deanship of Scientific Research Chairs. The authors also thank the Deanship of Scientific Research and RSSU at King Saud University for their technical support.

\section{REFERENCES CITED}

Abdel-Sattar, M. A., El-Marzoky, H. A., and Mohamed, A. I. (2008). “Occurrence of soilborne diseases and root knot nematodes in strawberry plants grown on compacted rice straw bales compared with naturally infested soil," Journal of Plant Protection Research 48(2), 223-235. DOI: 10.2478/v10045-008-0026-5

Adonizio, A. L., Downum, K., Bennett, B. C., and Mathee, K. (2006). “Anti-quorum sensing activity of medicinal plants in southern Florida," Journal of Ethnopharmacolology 105(3), 427-435. DOI: 10.1016/j.jep.2005.11.025

Ahmed, M. F. A., and El-Fiki, I. A. I. (2017). "Effect of biological control of root rot diseases of strawberry using Trichoderma spp.," Middle East Journal of Applied Sciences 7(3), 482-492.

Al-Huqail, A. A., Behiry, S. I., Salem, M. Z. M., Ali, H. M., Siddiqui, M. H., and Salem, A. Z. M. (2019). "Antifungal, antibacterial, and antioxidant activities of Acacia saligna (Labill.) H. L. Wendl. flower extract: HPLC analysis of phenolic and flavonoid compounds," Molecules 24(4), Article Number 700. DOI: 10.3390/molecules 24040700

Ali, H. M., Salem, M. Z. M., and Abdel-Megeed, A. (2013). "In-vitro antibacterial activities of alkaloids extract from leaves of Conocarpus lancifolius Engl.," Journal of Pure Applied Microbiology 7(3), 1903-1907.

Alves, C. T., Ferreira, I. C., Barros, L., Silva, S., Azeredo, J., and Henriques, M. (2014). "Antifungal activity of phenolic compounds identified in flowers from North Eastern Portugal against Candida species," Future Microbiology 9(2), 139-146. DOI: 10.2217/fmb.13.147 
Arima, H., Ashida, H., and Danno, G. (2002). "Rutin-enhanced antibacterial activities of flavonoids against Bacillus cereus and Salmonella enteritidis," Bioscience, Biotechnology, and Biochemistry 66(5), 1009-1014. DOI: 10.1271/bbb.66.1009

Ashmawy, N. A., Al Farraj, D. A., Salem, M. Z. M., Elshikh, M. S., Al-Kufaidy, R., Alshammari, M. K., and Salem, A. Z. M. (2018a). "Potential impacts of Pinus halepensis Miller trees as a source of phytochemical compounds: Antibacterial activity of the cones essential oil and n-butanol extract," Agroforestry System (Online), 1-11. DOI: 10.1007/s10457-018-0324-5

Ashmawy, N. A., Behiry, S. I., Ali, H. M., and Salem, M. Z. M. (2014). "Evaluation of Tecoma stans and Callistemon viminalis extracts against potato soft rot bacteria in vitro," Journal of Pure and Applied Microbiology 8(Suppl. Edn. 2), 667-673.

Ashmawy, N. A., Jadalla, N. M., Shoeib, A. A., and El-Bebany, A. F. (2015a). "Identification and genetic characterization of Pectobacterium spp. and related enterobacteriaceae causing potato soft rot diseases in Egypt," Journal of Pure and Applied Microbiology 9(3), 1847-1858.

Ashmawy, N. A., Zaghloul, T. I., and El-Sabagh, M. A. (2015b). "Isolation and molecular characterization of the fire blight pathogen, Erwinia amylovora, isolated from apple and pear orchards in Egypt," Plant Pathology Journal 14(3), 142-147. DOI: $10.3923 /$ ppj.2015.142.147.

Ashmawy, N. A., Salem, M. Z. M., EL-Hefny, M., Abd El-Kareemd, M. S. M., ElShanhorey, N. A., Mohamed, A. A., and Salem, A. Z. M. (2018b). "Antibacterial activity of the bioactive compounds identified in three woody plants against some pathogenic bacteria," Microbial Pathogenesis 121, 331-340. DOI:

10.1016/j.micpath.2018.05.032

Ashmawy, N. A., El-Bebany A. F. Shams, A.H.M and Shoeib A. A. (2020). "Identification and differentiation of soft rot and blackleg bacteria from potato using nested and multiplex PCR," Journal of Plant Diseases and Protection 127, 141-153. DOI: $10.1007 / \mathrm{s} 41348-019-00257-1$.

Ashmawy, N. A., Zaghloul, T. I., and El-Sabagh, M. A. (2015b). "Isolation and molecular characterization of the fire blight pathogen, Erwinia amylovora, Isolated from apple and pear orchards in Egypt," Plant Pathology Journal 14(3), 142-147. DOI: $10.3923 / p p j .2015 .142 .147$

Awad, H. M. (2017). "Antifungal potentialities of chitosan and Trichoderma in controlling Botrytis cinerea, causing strawberry gray mold disease," Journal of Plant Protection and Pathology 8(8), 371- 378. DOI: 10.21608/jppp.2017.46342

Ayaz, F., HayIrlIoglu-Ayaz, S., Alpay-Karaoglu, S., Gruz, J., Valentová, K., Ulrichová, J., and Strnad, M. (2008). "Phenolic acid contents of kale (Brassica oleraceae L. var. acephala DC.) extracts and their antioxidant and antibacterial activities," Food Chemistry 107(1), 19-25. DOI: 10.1016/j.foodchem.2007.07.003

Behiry, S. I., Ashmawy, N. A., Abdelkhalek, A. A, Younes, H. A., Khaled, A. E., and Hafez, E. E. (2018a). "Compatible- and incompatible-type interactions related to defense genes in potato elucidation by Pectobacterium carotovorum," Journal of Plant Diseases and Protection 125(2), 197-204. DOI: 10.1007/s41348-017-0125-5

Behiry, S. I., EL-Hefny, M., and Salem, M. Z. M. (2019a). "Toxicity effects of Eriocephalus africanus L. leaf essential oil against some molecularly identified phytopathogenic bacterial strains," Natural Product Research (Online). DOI: 10.1080/14786419.2019.1566824 
Behiry, S. I., Mohamed, A. A., Younes, H. A., Salem, M. Z. M., and Salem, A. Z. M. (2018b). "Antigenic and pathogenicity activities of Ralstonia solanacearum race 3 biovar 2 molecularly identified and detected by indirect ELISA using polyclonal antibodies generated in rabbits," Microbial Pathogenesis 115, 216-221. DOI: 10.1016/j.micpath.2017.12.060

Behiry, S. I., Okla, M. K., Alamri, S. A., EL-Hefny, M., Salem, M. Z. M., Alaraidh, I. A., Ali, H. M., Al-Ghtani, S. M., Monroy, J. C., and Salem, A. Z. M. (2019b). "Antifungal and antibacterial activities of Musa paradisiaca L. peel extract: HPLC analysis of phenolic and flavonoid contents," Processes 7, Article Number 215. DOI: 10.3390/pr7040215

Behiry, S., Nasser, R. S. M., Abd El-Kareem, M., Ali, H., and Salem, M. (2020). "Mass spectroscopic analysis, MNDO quantum chemical studies and antifungal activity of essential and recovered oil constituents of lemon-scented gum against three common molds," Processes 8(3), 275. DOI: 10.3390/pr8030275.

Boulogne, I., Germosén-Robineau, L., Ozier-Lafontaine, H., Fleury, M., and LorangerMerciris, G. (2011). "TRAMIL ethnopharmalogical survey in Les Saintes (Guadeloupe, French West Indies): A comparative study," Journal of Ethnopharmacolology 133(3), 1039-1050. DOI: 10.1016/j.jep.2010.11.034

Campos, M. R., Ruiz, J., Chel-Guerrero, L., and Ancona, D. (2015). "Coccoloba uvifera L. (Polygonaceae) fruit: Phytochemical screening and potential antioxidant activity," Journal of Chemistry 2015, Article ID 534954. DOI: 10.1155/2015/534954

Coe, F., and Anderson, G. (1996). "Screening of medicinal plants used by the Garífuna of Eastern Nicaragua for bioactive compounds," Journal of Ethnopharmacology 53(1), 29-50. DOI: 10.1016/0378-8741(96)01424-9

Compagnone, R., Castillo, S. A., and Delle, M. F. (1995). "Myricetin-3-O-rhamnoside from the leaves and twigs of Coccoloba dugandiana," Revista Colombiana de Química 24(2), 65-68.

Cota, B. B., Oliveira, A. B., Souza Filho, J. D., and Braga, F. C. (2003). "Antimicrobial activity and constituents of Coccoloba acrostichoides," Fitoterapia 74(7-8), 729-731. DOI: 10.1016/j.fitote.2003.08.003

DeCleene, M., and DeLey, J. (1976). "The host range of crown gall," The Botanical Review 42(4), 389-466. DOI: 10.1007/BF02860827

Dhingra, O. D., and Sinclair, J. B. (1985). Basic Plant Pathology Methods, CRC Press, Boca Raton, FL, USA.

EL-Hefny, M., Ali, H. M., Ashmawy, N. A., and Salem, M. Z. M. (2017a). "Chemical composition and bioactivity of Salvadora persica extracts against some potato bacterial pathogens," BioResources 12(1), 1835-1849. DOI: 10.15376/biores.12.1.1835-1849

EL-Hefny, M., Ashmawy, N. A., Salem, M. Z. M., and Salem, A. Z. M. (2017b). "Antibacterial activity of the phytochemicals-characterized extracts of Callistemon viminalis, Eucalyptus camaldulensis and Conyza dioscoridis against the growth of some phytopathogenic bacteria," Microbial Pathogenesis 113, 348-356. DOI: 10.1016/j.micpath.2017.11.004

EL-Hefny, M., Abo Elgat, W.A. A., Al-Huqail, A. A., and Ali, H. (2019). "Essential and recovery oils from Matricaria chamomilla flowers as environmentally friendly fungicides against four fungi isolated from cultural heritage objects," Processes 2019, 7, 809. DOI: $10.3390 / p r 7110809$ 
EL-Hefny, M., Salem, M., Behiry, S., and Ali, H. (2020). "The potential antibacterial and antifungal activities of wood treated with Withania somnifera fruit extract, and the phenolic, caffeine, and flavonoid composition of the extract according to HPLC," Processes 8(1), 113. DOI: 10.3390/pr8010113.https://www.mdpi.com/2227$9717 / 8 / 1 / 113$

Fang, X. D., Finnegan, M. P., and Barbetti, M. J. (2013). "Wide variation in virulence and genetic diversity of binucleate Rhizoctonia isolates associated with root rot of strawberry in western Australia," PLoS ONE 8(2), e55877. DOI:

10.1371/journal.pone.0055877

Geiser, D. M., Jiménez-Gasco, M. D. M., Kang, S., Makalowska, I., Veeraraghavan, N., Ward, T. J., Zhang, N., Kuldau, G. A., and O'Donnell, K. (2004). "FUSARIUM-ID v. 1.0: A DNA sequence database for identifying Fusarium," European Journal of Plant Pathology 110(5-6), 473-479. DOI: 10.1023/B:EJPP.0000032386.75915.a0

Hendra, R., Ahmad, S., Sukari, A., Shukor, M. Y., and Oskoueian, E. (2011). "Flavonoid analyses and antimicrobial activity of various parts of Phaleria macrocarpa (Scheff.) Boerl Fruit," International Journal of Molecular Sciences 12(6), 3422-3431. DOI: 10.3390/ijms12063422

Juber, K. S., Al-Juboory, H. H., and Al-Juboory, S. B. (2014). "Fusarium wilt disease of strawberry caused by Fusarium oxysporum f. sp. Fragariae in Iraq and its control," Journal of Experimental Biology and Agriculture Sciences 2(4), 419-427. DOI: 10.13140/RG.2.2.35459.14889

Kaewpiboon, C., Lirdprapamongkol, K., Srisomsap, C., Winayanuwattikun, P., Yongvanich, T., Puwaprisirisan, P., Svasti, J., and Assavalapsakul, W. (2012). "Studies of the in vitro cytotoxic, antioxidant, lipase inhibitory and antimicrobial activities of selected Thai medicinal plants," BMC Complementary and Alternative Medicine 12, Article Number 217.

Kiehlbauch, J. A., Hannett, G. E., Salfinger, M., Archinal, W., Monserrat, C., and Carlyn, C. (2000). "Use of the National Committee for Clinical Laboratory Standards guidelines for disk diffusion susceptibility testing in New York State laboratories," Journal of Clinical Microbiology 38(9), 3341-3348.

Li, X. C., Elsohly, H. N., Nimrod, A. C., and Clark, A. M. (1999). "Antifungal activity of (-)-epigallacatechin gallate from Coccoloba dugandiana," Planta Medica 65(8), 780. DOI: $10.1055 / \mathrm{s}-2006-960871$

Lopes, L. A. A., Dos Santos Rodrigues, J. B., Magnani, M., De Souza, E. L., and De Siqueira, Jr., J. P. (2017). "Inhibitory effects of flavonoids on biofilm formation by Staphylococcus aureus that overexpresses efflux protein genes," Microbial Pathogenesis 107(6), 193-197. DOI: 10.1016/j.micpath.2017.03.033

Malathi, S., Masilamani, P., Balasubramanian, V., Rao, R. B., and Brindha, P. (1995). "Constituents of Coccoloba uvifera leaves," Fitoterapia 66(3), Article Number 277.

Mansour, M. M. A., and Salem, M. Z. M. (2015). "Evaluation of wood treated with some natural extracts and Paraloid B-72 against the fungus Trichoderma harzianum: Wood elemental composition, in-vitro and application evidence," International

Biodeterioration \& Biodegradation 100(5), 62-69. DOI: 10.1016/j.ibiod.2015.02.009

Mansour, M. M. A., Abdel-Megeed, A., Nasser, R. A., and Salem, M. Z. M. (2015).

"Comparative evaluation of some woody tree methanolic extracts and Paraloid B-72 against phytopathogenic mold fungi Alternaria tenuissima and Fusarium culmorum," BioResources 10(2), 2570-2584. DOI: 10.15376/biores.10.2.2570-2584 
Meléndez, P. A., and Capriles, V. A. (2006). "Antibacterial properties of tropical plants from Puerto Rico,” Phytomedicine 13(4), 272-276. DOI:

10.1016/j.phymed.2004.11.009

Mierziak, J., Kostyn, K., and Kulma, A. (2014). "Flavonoids as important molecules of plant interactions with the environment," Molecules 19(10), 16240-16265. DOI: 10.3390/molecules191016240

Mingzhu, L. (2011). "A multiplex PCR for the detection of Phytophthora nicotianae and $P$. cactorum and a survey of their occurrence in strawberry production areas of Japan," Plant Disease 95(10), 1270-1278. DOI: 10.1094/PDIS-01-11-0076

Mohamed, A. A., Behiry, S. I., Younes, H. A., Ashmawy, N. A., Salem, M. Z. M., Márquez-Molina, O., and Barbabosa-Pilego, A. (2019). "Antibacterial activity of three essential oils and some monoterpenes against Ralstonia solanacearum phylotype II isolated from potato," Microb. Pathogenesis 135, Article ID 103604. DOI: $10.1016 /$ j.micpath.2019.103604

Mohamed, A., Behiry, S., Ali, H., EL-Hefny, M., Salem, M., Ashmawy, N. (2020). "Phytochemical compounds of branches from $P$. halepensis oily liquid extract and $S$. terebinthifolius essential oil and their potential antifungal activity," Processes 8(3), 330. DOI: 10.3390/pr8030330.

Moreno-Morales, S., Crescente-Vallejo, O., Henríquez-Guzmán, W., Liendo-Polanco, G., and Herrera-Mata, H. (2008). "Three constituents with biological activity from Coccoloba uvifera seeds," Ciencia 6(1), 84-89.

Okla, M. K., Alamri, S. A., Salem, M. Z. M., Ali, H. M., Behiry, S. I., Nasser, R. A., and Soufan, W. (2019). "Yield, phytochemical constituents, and antibacterial activity of essential oils from the leaves/twigs, branches, branch wood, and branch bark of sour orange (Citrus aurantium L.)," Processes 7(6), Article Number 363. DOI: 10.3390/pr7060363

Oliveira, P. E., Dos Santos, W. S., Conserva, L. M., and De Lyra Lemos, R. P. (2008). "Chemical constituents from leaves and stem of Coccoloba mollis Casaretto (Polygonaceae)," Revista Brazilian Journal of Pharmacognosy 18, 713-717. DOI: 10.1590/S0102-695X2008000500014

Oliveira, V. M., Carraro, E., Auler, M. E., and Khalil, N. M. (2016). "Quercetin and rutin as potential agents antifungal against Cryptococcus spp.," Brazilian Journal of Biology 76(4), 1029-1034. DOI: 10.1590/1519-6984.07415

Perez, S., Zavala, M. A., Arias, L., Perez, C., and Perez, R. M. (2001). “Antimicrobial study of bark from five tree species," Phytotheraby Research 15(4), 356-359. DOI: $10.1002 /$ ptr.726

Pimentel, D., and Levitan, L. (1986). "Pesticides: Amounts applied and amounts reaching pests," Bioscience 36(2), 86-91. DOI: 10.2307/1310108

Pitman, A., Harrow, S., and Visnovsky, S. (2010). "Genetic characterisation of Pectobacterium wasabiae causing soft rot disease of potato in New Zealand," European Journal of Plant Pathology 126(3), 423-435. DOI: 10.1007/s10658-0099551-y

Povi, L.-E., Batomayena, B., Hodé, T. A., Kwashie, E.-G., Kodjo, A., and Messanvi, G. (2015). "Phytochemical screening, antioxidant and hypoglycemic activity of Coccoloba uvifera leaves and Waltheria indica roots extracts," International Journal of Pharmacy and Pharmaceutical Sciences 7(5), 279-283. 
Rahman, M., and Moon, S. (2007). "Antimicrobial phenolic derivatives from Dendranthema zawadskii var. latilobum kitamura (Asteraceae)," Archives of Pharmacal Research 30(11), 1374-1379. DOI: 10.1007/BF02977359

Rajendran, N., Subramaniam, S., Christena, L. R., Muthuraman, M. S., Subramanian, N. S., Pemiah, B., and Sivasubramanian, A. (2016). "Antimicrobial flavonoids isolated from Indian medicinal plant Scutellaria oblonga inhibit biofilms formed by common food pathogens," Natural Product Research 30(17), 2002-2006. DOI: 10.1080/14786419.2015.1104673

Rodríguez-García, C. M., Ruiz-Ruiz, J. C., Peraza-Echeverría, L., Peraza-Sánchez, S. R., Torres-Tapia, L. W., Pérez-Brito, D., Tapia-Tussell, R., Herrera-Chalé, F. G., SeguraCampos, M. R., Quijano-Ramayo, A., et al. (2019). “Antioxidant, antihypertensive, anti-hyperglycemic, and antimicrobial activity of aqueous extracts from twelve native plants of the Yucatan coast," PLoS ONE 14(3), e0213493. DOI:

10.1371/journal.pone.0213493

Salem, M. Z. M., Ali, H. M., El-Shanhorey, N. A., and Abdel-Megeed A. (2013). "Evaluation of extracts and essential oil from Callistemon viminalis leaves: Antibacterial and antioxidant activities, total phenolic and flavonoid contents," Asian Pacific Journal of Tropical Medicine 6(10), 785-791. DOI: 10.1016/S19957645(13)60139-X

Salem, M. Z. M., Zidan, Y. E., Mansour, M. M. A., El Hadidi, N. M. N., and Abo Elgat, W. A. A. (2016a). "Evaluation of usage three natural extracts applied to three commercial wood species against five common molds," International Biodeterioration \& Biodegradation 110(5), 206-226. DOI: 10.1016/j.ibiod.2016.03.028

Salem, M. Z. M., Zidan, Y. E., Mansour, M. M. A., El Hadidi, N. M. N., and Abo Elgat, W. A. A. (2016b). "Antifungal activities of two essential oils used in the treatment of three commercial woods deteriorated by five common mold fungi," International Biodeterioration \& Biodegradation 106(1), 88-96. DOI: 10.1016/j.ibiod.2015.10.010

Salem, M. Z. M., Behiry, S. I., and Salem, A. Z. M. (2018). "Effectiveness of root-bark extract from Salvadora persica against the growth of certain molecularly identified pathogenic bacteria," Microbial Pathogenesis 117, 320-326. DOI: 10.1016/j.micpath.2018.02.044

Salem, M. Z. M., Behiry, S. I., and EL-Hefny, M. (2019a). "Inhibition of Fusarium culmorum, Penicillium chrysogenum and Rhizoctonia solani by n-hexane characterized extracts of three plant species as a wood-treated oil-fungicide model," Journal of Applied Microbiology 126(6), 1683-1699. DOI: 10.1111/jam.14256

Salem, M. Z. M., Mansour, M. M. A., and Elansary, H. O. (2019b). "Evaluation of the effect of inner and outer bark extracts of sugar maple (Acer saccharum var. saccharum) in combination with citric acid against the growth of three common molds," Journal of Wood Chemistry and Technology 39(2), 136-147. DOI: 10.1080/02773813.2018.1547763

Salih, E. Y. A., Fyhrquist, P., Abdalla, A. M. A., Abdelgadir, A. Y., Kanninen, M., Sipi, M., Luukkanen, O., Fahmi, M. K. M., Elamin, M. H., and Ali, H. A. (2017). "LCMS/MS tandem mass spectrometry for analysis of phenolic compounds and pentacyclic triterpenes in antifungal extracts of Terminalia brownii (Fresen)," Antibiotics 6(4), 37. DOI: 10.3390/antibiotics6040037 
Sharma, A., Flores-Vallejo, R. C., Cardoso-Taketa, A., and Villarreal, M. L. (2017). "Antibacterial activities of medicinal plants used in Mexican traditional medicine," Journal of Ethnopharmacology 208(8), 264-329. DOI: 10.1016/j.jep.2016.04.045

Shaw, P. E., Moshonas, M. G., and Baldwin, E. A. (1992). "Volatile constituents of Coccoloba uvifera," Phytochemistry 31(10), 3495-3497. DOI: 10.1016/00319422(92)83714-A

Silva, J. P., Peres, A. R., Paixão, T. P., Silva, A. S., Baetas, A. C., Barbosa, W. L., Monteiro, M. C., and Andrade, M. A. (2017). "Antifungal activity of hydroalcoholic extract of Chrysobalanus icaco against oral clinical isolates of Candida species," Pharmacognosy Research 9(1), 96-100. DOI: 10.4103/0974-8490.199772

Singh, G., and Kumar, P. (2013). "Phytochemical study and screening for antimicrobial activity of flavonoids of Euphorbia hirta," International Journal of Applied and Basic Medical Research 3(2), 111-116. DOI: 10.4103/2229-516X.117082

Soares de Araújo Pinho, F. V., Cezar da Cruz, L., Rodrigues, N. R., Waczuk, E. P., Souza, C. E., Coutinho, H. D. M., Martins da Costa, J. G., Athayde, M. L., Boligon, A. A., Franco, J. L., et al. (2016). "Phytochemical composition, antifungal and antioxidant activity of Duguetia furfuracea A. St.-Hill.," Oxidative Medicine and Cellular Longevity 2016, Article ID 7821051. DOI: 10.1155/2016/7821051

Taechowisan, T., Sarakoat, P., and Phutdhawong, W. S. (2019). "Major chemical composition of fruit extracts of Morinda citrifolia L. and their antibacterial, antioxidant and cytotoxicity properties," Journal of Applied Sciences 19(5), 366-375. DOI: $10.3923 /$ jas.2019.366.375

Tempesti, T. C., Alvarez, M. G., De Araújo, M. F., Júnior, F. E., De Carvalho, M. G., and Durantini, E. N. (2012). "Antifungal activity of a novel quercetin derivative bearing a trifluoromethyl group on Candida albicans," Medicinal Chemistry Research 21(9), 2217-2222. DOI: 10.1007/s00044-011-9750-x

Ustün, O., Ozçelik, B., Akyön, Y., Abbasoglu, U., and Yesilada, E. (2006). "Flavonoids with anti-Helicobacter pylori activity from Cistus laurifolius leaves," Journal of Ethnopharmacology 108(3), 457-461. DOI: 10.1016/j.jep.2006.06.001

Van der Wolf, J. M., and De Boer, S. H. (2007). "Bacterial pathogens of potato," in: Potato Biology and Biotechnology, D. V. Bradshaw, C. Gebhardt, F. Govers, D. K. L. Mackerron, M. A. Taylor, and H. A. Ross (eds.), Elsevier Science B.V., Amsterdam, Netherlands, pp. 595-617.

Vaquero, M. J. R., Alberto, M. R., and De Nadra, M. C. M. (2007). “Antibacterial effect of phenolic compounds from different wines," Food Control 18(2), 93-101. DOI: 10.1016/j.foodcont.2005.08.010

Weidenbörner, M., Hindorf, H., Jha, H. C., and Tsotsonos, P. (1990). "Antifungal activity of flavonoids against storage fungi of the genus Aspergillus," Phytochemistry 29(4), 1103-1105. DOI: 10.1016/0031-9422(90)85412-9

White, T. J., Bruns, T., Lee, S., and Taylor, J. (1999). “Amplification and direct sequencing of fungal ribosomal RNA genes for phylogenetics," in: PCR Protocols: A Guide to Methods and Applications, M. A. Innes, D. H. Gelfand, J. J. Sninsky, and T. J. White (eds.), Academic Press, Inc., New York, NY, USA, pp. 315-322. 
Young, J. M., Kuykendall, L. D., Martínez-Romero, E., Kerr, A., and Sawada, H. (2001). "A revision of Rhizobium Frank 1889, with an emended description of the genus, and the inclusion of all species of Agrobacterium Conn 1942 and Allorhizobium undicola de Lajudie et al. 1998 as new combinations: Rhizobium radiobacter, $R$. rhizogenes, $R$. rubi, $R$. undicola and $R$. vitis," International Journal of Systematic and Evolutionary Microbiology 51(1), 89-103. DOI: 10.1099/00207713-51-1-89

Article submitted: November 5, 2019; Peer review completed: March 8, 2020; Revised version received and accepted: April 10, 2020; Published: April 15, 2020.

DOI: 10.15376/biores.15.2.4165-4187 